\title{
IMPLEMENTASI PROGRAM PERLINDUNGAN LAHAN PERTANIAN PANGAN BERKELANJUTAN (PLP2B) DI KABUPATEN GARUT JAWA BARAT (Kasus di Desa Jati Kecamatan Tarogong Kaler Kabupaten Garut)
}

\author{
I. Iskandar ${ }^{1 \mathrm{a}}, \mathrm{H}$. Miftah $^{1,} \mathrm{~A}$. Yusdiarti ${ }^{1}$ \\ ${ }^{1}$ Jurusan Agribisnis, Fakultas Pertanian Universitas Djuanda Bogor \\ Jalan Tol Ciawi No. 1 Kotak Pos 35 Bogor 16720 \\ ${ }^{a}$ Korespondensi : Imam Iskandar Telp : 08989419705; E-mail : imam.iskandar7@gmail.com
}

\begin{abstract}
The aim of this research is to identify the development and process of Implementation Program the Protection of Agricultural Land in Garut Sustainable Food and knowing perception against Peasant level of importance of atribute PLP2B along Relations Program Farmers characteristics The Perception Importance of Agricultural artribut PLP2B Program. The research using descriptive analysis and Spearman Rank Correlation analysis with Excel program using Microsoft Office 2007 and SPSS 20. Results of the research show that the aim implemantation of farmland protection program phase documenting sustainable food is the name by addres 442 villages in Garut, while the village is well documenting performed a total of 208 villages. Against the perception of the level of interest Farmer attributes Farmland Protection Program Sustainable Food in Garut shows that farmers against revenue program is on important category averaging scores with a total of 3.09 shows that the farmers gives perception against Farmers Farmland Protection Program Sustainable Food Good. Relations between the perception farmers and characteristic term dependents, land, and Real Income influential not perception against peasant while Age, experience the real influential farming and income $(\mathrm{p}<0.05)$ perception against peasant. Correlation relationship Age, farming experience, term dependents, land education and correlates weak revenue official.
\end{abstract}

Keywords: PLP2B Program, Implementation, Perceptions

\begin{abstract}
ABSTRAK
Penelitian ini bertujuan untuk mengidentifikasi perkembangan dan proses implementasi Program Perlindungan Lahan Pertanian Pangan Berkelanjutan di Kabupaten Garut dan mengetahui persepsi tingkat kepentingan petani terhadap atribut program PLP2B berserta hubungan karakteristik petani dengan persepsi tingkat kepentingan pertani terhadap artribut program PLP2B. Penelitian ini menggunakan analisis deskriptif dan analisis Korelasi Rank Spearman dengan menggunakan program microsoft office excel 2007 dan SPSS 20. Hasil penelitian ini menunjukkan bahwa Implemantasi Program Perlindungan Lahan Pertanian Pangan Berkelanjutan berada tahap pendataan by name by addres 442 desa di Kabupaten Garut, sedangkan desa yang sudah dilakukan pendataan sebanyak 208 desa. Persepsi tingkat kepentingan petani terhadap atribut program perlindungan lahan pertanian pangan berkelanjutan di Kabupaten Garut menunjukkan bahwa penerimaan petani terhadap program berada pada kategori penting dengan total rataan skor 3,09. Ini menunjukan bahwa petani memberikan persepsi terhadap program perlindungan lahan pertanian pangan berkelanjutan baik.Hubungan antara persepsi petani dan karatkteristik jumlah tanggungan, luas lahan, dan pendapatan tidak berpengaruh nyata terhadap persepsi petani sedangkan umur,pengalaman usahatani dan pendapatan berpengaruh nyata $(\mathrm{p}<0,05)$ terhadap persepsi petani. Korelasi hubungan umur, pengalaman usahatani, jumlah tanggungan ,luas lahan pendidikan formal dan pendapatan berkolerasi lemah.
\end{abstract}

Kata Kunci : Program PLP2B, Implementasi, Persepsi 


\section{PENDAHULUAN}

Indonesia adalah negara yang memiliki sumberdaya alam yang luas khususnya dalam bidang pertanian. Indonesia termasuk negara agraris, dimana masyarakatnya masih tergantung pada sektor pertanian khususnya pada komoditi padi. Penurunan produksi diperkirakan terjadi karena penurunan lahan seluas 41,61 ribu hektar $(0,30 \%)$ dan penuruan produktivitas sebesar $0,17 \mathrm{Ku} / \mathrm{Ha}(0,33)$ dibandingkan pada tahun 2013 (BPS, 2015). Penurunan luas lahan pertanian ini disebabkan adanya alih fungsi lahan dari lahan pertanian beralih ke lahan non pertanian.

Upaya pemerintah untuk mencegah alih fungsi lahan pertanian ke non pertanian dan menjaga kesedian pangan salah satunya yaitu dengan dikeluarkannya program perlindungan lahan pertanian pangan berkelajutan (PLP2B). Program tersebut berdasarakan amanat dari UU No 41 Tahun 2009 tentang perlindungan lahan pertanian pangan berkelanjutan.

Kabupaten Garut adalah salah satu daerah yang mendukung program PLP2B, hal ini dapat dilihat dari PERDA No 29 tahun 2011 tentang Rencana Tata Ruang dan Wilayah (RTRW) Kabupaten Garut. Dalam rangka mengimplementasikan Undang - Undang No 41 tahun 2009 tersebut, Kabupaten Garut melakukan penataan dengan memperhatikan lahan pertanian untuk menimbangi alih fungsi lahan yang berdampak pada produktivitas pangan yang semakin menurun.

Berdasarkan uraian di atas timbul pertanyaan Bagaimana implementasi program perlindungan lahan pertanian pangan berkelanjutan di Kabupaten Garut, Bagaimana persepsi tingkat kepentingan petani terhadap atribut program PLP2B, Bagaimana hubungan karakteristik petani dengan persepsi petani terhadap penerimaan program PLP2B.

Penelitian ini bertujuan untuk

Mengidentifikasi perkembangan dan proses implementasi program perlindungan lahan pertanian pangan berkelanjutan di Kabupaten Garut.Mengetahui persepsi tingkat kepentingan petani terhadap atribut program PLP2B. Mengetahui hubungan karakteristik petani dengan persepsi tingkat kepentingan pertani terhadap atribut program PLP2B.

\section{BAHAN DAN METODE}

\section{Pengertian Implementasi Kebijakan}

Implementasi kebijakan adalah suatu proses melaksanakan kebijaksanaan. Biasanya dalam bentuk undang-undang, peraturan pemerintah, keputusan pengadilan, perintah eksekutif, atau dekrit presiden (Wahab, 2008). Implementasi kebjiakan pada

perinsipnya adalah cara agar sebuah kebijakan dapat mencapai tujuan. Untuk mengimplementasikan kebijakan publik, maka ada dua pilihan langkah yang ada, yaitu langsung mengimplementasikan dalam bentuk program-program atau melalui formulasi kebijakan turunan dari kebijakan publik tersebut (Riant, 2003).

\section{Konsep Perlindungan Lahan Pertanian Pangan Berkelanjutan}

Pertanian berkelanjutan adalah sumberdaya untuk menghasilkan kebutuhan pokok manusia, yaitun sandang, pangan dan papan, sekaligus mempertahankan dan meningkatkan kualitas lingkungan dan melestarikannya. Defisnisi hal - hal tersebut mencangkup penataan secara ekologi, bisa berlanjut secara ekonomi, adil, manusiawi, dan luwes (Sabiham, 2008).

\section{Pengertian Persepsi}

Persepi adalah pengalaman seseorang tentang obyek, peristiwa atau hubungan-hubungan yang diperoleh dengan menyimpulkan informasi dan menafsirkan pesan. Persepsi adalah pandangan atau sikap terhadap sesuatu hal yang menumbuhkan motivasi, dorongan, kekuatan dan tekanan yang menyebabkan 
seseorang melakukan atau tidak melakukan sesuatu (Rakhmat, 2004).

\section{Analisis Korelasi (Rank Spearman)}

Koefisien rank spearman digunakan untuk mengetahui ada tidaknya hubungan antara Karakteristik petani dan persepsi petani terhadap penerimaan program PLP2B. Nazir (2005) menyatakan jika pengamatan dari dua variabel dalam bentuk ordinal, maka derajat kolerasinya dapat dicari dengan koefisien korelasi rank spearman. Uji statistik nonparametrik, pengukurannya berupa respon kualitatif atau nilai nilai pada skala ordinal. Pada skala ordinal, subyek terdiri atas peringkat menurut urutan tertentu dan menganalisis peringkat-peringakat tersebut.

\section{Metode Penelitian}

Penelitian mengenai implementasi program perlindungan lahan pertanian pangan berkelanjutan ini dilakukan di Desa Jati Kecamatan Tarogong Kaler Kabupaten Garut Provinsi Jawa Barat. Pemilihan lokasi ini dilakukan dengan pruposive, dengan pertimbangan bahwa Desa Jati Kecamatan Tarogong Kaler dekat dengan perkotaan dan rawan terjadinya alih fungsi lahan. Pengumpulan data dilakukan pada bulan September 2015.

Analisis data dilakukan secara kualitatif dan kuantitatif. data kualitatif menggunakan analisis deskriptif yang berguna untuk menganalisis data yang menggambarkan, meringkas berbagai kondisi, dan berbagai situasi program PLP2B dan mendeskriptifkan persepsi tingkat kepentingan petani terhadap atribut program PLP2B. Pengelolahan data kuantitatif menggunakan program SPSS versi 20.0 for window dan microsoft office excel 2007 untuk mengetahui hubungan antara karakteristik petani dengan persepsi tingkat kepentingan petani terhadap atribut programPLP2B. Uji hubungan antara variabel mengunakan metode statistik nonprametri yaitu analisis korelasi Rank Spearman.

\section{HASIL DAN PEMBAHASAN}

\section{Tahap Perencanaan}

Pemerintah Kabupaten Garut melakukan penetapan kawasan lahan perlindungan pertanian pangan berkelanjutan sebagai langkah mengantisipasi terus berkurang berkurangnya lahan pertanian, sekaligus juga merealisasikan amanat UU no 41 Tahun 2009 dan Perda no 29 Tahun 2011 tentang Rancana Tata Ruang dan Wilayah Kabupaten Garut. Salah satu upaya Pemerintah Kabupaten Garut dalam mencegah alih fungsi lahan pertanian pangan yaitu dengan Program Perlindungan Lahan Pertanian Pangan Berkelanjutan (PLP2B). Program Perlindungan Lahan Petanian Pangan Berkelanjutan di Kabupaten Garut Berdasarkan :

1. UU no 41 Tahun 2009 tentang Perlindungan Lahan pertanian pangan berkalanjutan.

2. PERDA Provinsi Jawa Barat No 27 Tahun 2010 tentang perlindungan lahan pertanian pangan berkelanjutan.

3. PP No 1 Tahun 2011 tentang penetapan dan alih fungsi lahan pertanian pangan berkelanjutan.

4. PP No 12 Tahun 2012 tentang insentif perlindungan lahan pertanian.

5. PP No 30 Tahun 2012 tentang pembiayaan perlindungan lahan pertanian pangan berkelanjutan.

6. PP No 25 Tahun 2012 tentang informasi lahan pertanian pangan berkelanjutan.

7. PERDA No 29 tahun 2011 tentang Rencana Tata Ruang dan Wilayah (RTRW) Kabupaten Garut.

Alih fungsi lahan pertanian produkstif di Kabupaten Garut selama ini mencapai 5-6 hektar per tahun sejak 2011 lalu. Alih fungsi lahan marak terjadi dikawasan perkotaan, meliputi Kecamatan Tarong Kidul, Tarogong Kaler, Banyuresmi, Karangpawitan, Cilawu, dan Garut Kota. 
Dinas Tanaman Pangan dan Hortikultura lahan yang berencana lahan yang diikuti sertakan harus jauh dari jalan raya dimana jarak lahan dari jalan raya untuk jalan Desa 10 meter - 15 meter, jalan Kabupaten $>15$ meter, sedangkan Provinsi $>20$ meter, namun jarak lahan dari jalan raya nantinya akan disesuikan dengan PERDA RTRW Kabupaten Garut.

\section{Tahap Sosialisasi}

Implementasi

Program

Perlindungan Lahan Pertanian Pangan Berkalenjutan dimulai dari tahun 2010 dimana pelaksanaanya yang dilakukan yaitu dengan melakukan sosialisasi UU no 41 Tahun 2009 kepada dinas-dinas Pemerintah Kabupaten Garut yang terkait dalam perencanaan program perlindungan lahan pertanian pangan berkelanjutan.

Pada tahun 2014 sosialisasi dilakukan kembali sosialisasi Program Perlindungan Lahan Pertanian Pangan Berkalanjutan yang diikuti oleh 42 Kecamatan di Kabupaten Garut. Sosialisasi tersebut dihadiri oleh Pak Camat atau yang mewakilkannya, Kepala Desa, Ketua GAPOKTAN, Ketua Kelompok Tani, Tokoh tani, Penyuluh, dan UPTD.

\section{Tahap Pendataan}

Di Tahun 2014 juga tim dari IPB melakukan pemetaan citra satelit lahan persawahan per petak untuk diidentifikasi, dimana hasil dari pemetaan lahan persawahan dari setiap petakkannya dibuat peta untuk mempermudah identifikasi lahan sawah yang nantinya akan ditetapkan sebagai lahan yang diusulkan untuk Program Perlindungan Lahan Pertanian Pangan Berlanjutan.

Pada tahun 2015 hasil dari pemetaan lahan persawahan tahun 2014 digunakan untuk mengindetifikasi masingmasing petak ke nomer petak menurut nama pemilik, alamat dan luas lahan. Lahan yang akan diusulkan yaitu lahan yang produktivitasnya masih baik dan diprediksi 15 tahun kedapan tidak mengalami alih fungsi lahan. Ketika penelitian ini berlangsung pelaksanaan program PLP2B masih melakukan pendataan by name by address 442 Desa di Kabupaten Garut, sedangkan Desa yang sudah dilakukan pendataan sebanyak 208 Desa.

\section{Tahap Pelaksanaan Program}

Pada tahap pelaksanaan Program Perlindungan Lahan Pertanian Pangan Berkelanjutan Pemerintah Kabupaten Garut belum dapat dilakukan, hal ini disebabkan pendataan luas lahan by name by addresss belum selasai sehingga usulan untuk luas lahan yang diajukkan untuk mengikuti program perlindungan lahan pertanian pangan berkelanjutan belum dapat diajukan dan belum ada payung hukum berupa PERDA Kabupaten Garut tentang perlindungan lahan pertanian pangan berkelanjutan.

\section{Hambatan}

Hambatan dalam implementasi Program Perlindungan Lahan Pertanian Pangan Berkelanjutan di Kabupten Garut antara lain dari petani yaitu:

1. Masih adanya pro dan kontra tentang sanksi yang akan diberikan jika petani yang mengikuti Program Perlindungan Lahan Pertanian Pangan Berkelanjutan mengalih fungsikan lahannya, menurut sebagian petani beranggapan bahwa sanksi yang diberikan terlalu berat

2. Adanya sistem bagi waris dimana lahan yang dipunyai petani akan di wariskan kepada anak-anaknya, hal ini mengakibatkan kepemilikan lahan yang berubah-ubah,

Hambatan dari Pemerintah Kabupetan dalam mengimplementasikan Program Perlindungan Lahan Pertanian Pangan Berkelanjutan antara lain yaitu (1) belum adanya PERDA Kabupaten Garut tentang perlindungan lahan pertanian pangan berkelanjutan (2) kepemilikan lahan yang 
berubah-ubah dari data yang sudah ada, sehingga dalam pendataan by name by address mengalami kesulitan (3) Dibutuhkan dana yang besar dalam pelaksanaan Program Perlindungan Lahan Pertanian mulai dari dana sosialisasi dan pendataan sampai dengan dana untuk pemberian insentif bagi petani yang mengikuti program.

\section{Persepsi Tingkat Kepentingan Petani Terhadap Atribut Program Perlindungan Lahan Pertanian Pangan Berkelanjutan di Kabupaten Garut}

Tingkat kepentingan petani terhadap program perlindungan lahan pertanian pangan berkelanjutan di Kabupaten Garut dalam penelitian ini terdiri dari atribut-atribut berdasarkan UU no 41 tahun 2009 tentang perlindungan lahan pertanian pangan berkelanjutan yang dikategorikan menjadi 5 indikator yang terdiri beberapa artibut disetiap indikator.

$$
\text { Berdasarkan Lampiran } 1
$$

menunjukkan atribut program yang memiliki tingkat kepentingan tertinggi dengan tingkat 1,5 adalah atribut program perlindungan lahan pertanian berkelanjutan berupa memperolah sarana produksi dan prasarana pertanian dan atribut ganti rugi akibat gagal panen. Hal ini dikarenakan dua hal tersebut sangat diharapkan oleh petani sangat berharap jika mengikuti Program Perlindungan Lahan Pertanian Pangan Berkelanjutan dapat membantu petani mengurangi biaya produksi dalam kegiatan usahatani yang dilakukan dan memberikan jaminan ganti rugi bila gagal panen.

Persepsi tingkat kepentingan petani terhadap atribut Program Perlindungan Lahan Pertanian Pangan Berkelanjutan di Kabupaten Garut berdasarkan Lampiran 2 menunjukkan bahwa penerimaan petani terhadap program berada pada kategori penting dengan total rataan skor 3,09. Ini menunjukan bahwa petani beranggapan bahwa program perlindungan lahan pertanian pangan berkelanjutan di
Kabupaten Garut penting untuk diimplementasikan.

Persepsi ini dikarenakan petani menganggap atribut-atribut program dapat membantu mengurangi beban biaya produksi dalam kegiataan usahataninya dengan memberikan insentif dan perlindungan kepada petani serta menjamin ketersedian lahan untuk kegiatan pertanian sebab rata-rata responden menjadikan petani sebagai mata pencaharian dimana lahan adalah faktor yang sangat penting dalam kegiatan usahatani yang dilakukan.

Program Perlindungan Lahan Pertanian Pangan Berkelanjutan berdasarkan UU no 41 tahun 2009 petani yang mengikuti Program Perlindungan Lahan Pertanian Pangan Berkelanjutan dilakukan pembinaan tentang Program Perlindungan Lahan Pertanian Pangan Berkalanjutan. Berdasarkan Lampiran 2 persepsi petani terhadap pembinaan berada pada kategori sangat penting dengan rataan skor 3,4. Hal ini menunjukan bahwa kegiataan pembinaan ini sangat dibutuhkan petani untuk lebih memahami lebih jauh tentang program perlindungan lahan pertanian pangan berkelanjutan di Kabupaten Garut.

Pemberian insentif diberikan pada petani yang mengikut program perlindungan lahan pertanian pangan berkelanjutan. Pemberian insentif ini untuk memberikan motivasi sehingga petani mau ikut dalam program perlindungan lahan pertanian pangan berkelanjutan dan bantuan sarana produksi kepada petani dalam menjalankan usahataninya sehingga petani tidak menjual lahannya dengan alasan keterbatasan modal dalam penjalankan usahataninya. Berdasarkan Lampiran 2 persepsi petani terhadap pemberian insentif berada pada kategori sangat penting dengan rataan skor 3,5. Hal ini menunjukkan persepsi petani terhadap pemberian Insentif sangat baik. Pemberian insentif ini sangat diharapakan oleh petani saat mengikuti program perlindungan lahan pertanian pangan berkelanjutan 
sebab sangat membantu petani dalam mengembangkan usahatani yang dilakukan.

\section{Hubungan Karakteristik Petani dengan Persepsi Tingkat Kepntingan Petani Terhadap Atribut Program Perlindungan Lahan Pertanian Pangan Berkelanjutan di Kabupaten Garut.}

Hubungan antara karakteristik petani dengan persepsi tingkat kepentingan pertani terhadap atribut Program Perlindungan Lahan Pertanian Pangan Berkelanjutan di Kabupaten Garut diukur dengan menggunakan rank spearman (data skala ordinal : umur, pengalaman bertani, jumlah tanggungan, pendidikan formal, pendapatan dan luas lahan). Hasil dari pengujian hubungan antara karakteristik petani dengan persepsi tingkat kepentingan petani terhadap atribut program perlindungan lahan pertanian pangan berkelanjutan di Kabupaten Garut dapat dilihat pada Lampiran 3.

Hasil uji Rank Spearman juga menunjukkan adanya pengaruh yang nyata antara umur dengan persepsi tingkat kepentingan petani terhadap atribut program perlindungan lahan pertanian pangan berkelanjutan. Pengaruh yang nyata ini menunjukan bahwa umur berpengaruh terhadap persepsi yang diberikan petani mengenai penerimaan Program Perlindungan Lahan Pertanian Pangan Berkelanjutan.

Hubungan antara umur petani dengan persepsi tingkat kepentingan petani terhadap atribut Program Perlindungan Lahan Pertanian Pangan Berkelanjutan memiliki hubungan yang positif artinya semakin bertambahnya umur, petani beranggapan bahwa program perlindungan lahan pertanian pangan berkelanjutan sangat penting namun dengan kolerasi yang lemah dengan nilai koefisian kolerasinya sebasar 0,315 .

Pengaruh nyata umur terhadap tingkat kepentingan petani terhadap atribut program pertanian pangan berkelanjutan ini disebabkan, petani dalam penelitian ini yang berumur lebih tua beranggapan bahwa melindungi lahan pertanian sangat penting dilakukan karena rata-rata petani adalah buruh tani dimana kesempatan berkerja diumur yang sudah lanjut sulit untuk mendapatkan pekerjaan sehingga bertani menjadi mata pencaharian dalam memenuhi kebutuhan hidup petani, maka dari itu lahan sebagai salah satu faktor penting dalam kegiataan pertanian harus dilindungi.

Hubungan antara pengalaman usahatani dengan persepsi tingkat kepentingan petani terhadap atribut Program Perlindungan Lahan Pertanian Pangan Berkelanjutan memiliki korelasi yang lemah sebesar 0,389. Ini menunjukkan bahwa pengalaman yang rendah, sedang dan berpangalaman memiliki persepsi yang sama terhadap penerimaan Program Perlindungan Lahan Pertanian Pangan Berkelanjutan. Hasil uji Rank Spearman juga menunjukkan bahwa hubungan pengalaman usahatani dengan persepsi tingkat kepentingan petani terhadap atribut Program Perlindungan Lahan Pertanian Pangan Berkelanjutan berpengaruh nyata $(p<0,05)$.

Hubungan nyata antara pengalaman usahatani dengan persepsi tingkat kepentingan petani ini dikarenakan petani yang memiliki pengalaman usahatani yang lebih banyak beranggapan melindungi lahan pertanian sangatlah penting, dengan pengalaman usahataninya petani tahu betul keuntungan menjaga lahan pertanian mulai dari keuntungan secara ekonomi sampai dengan keuntungan secara ekologi. Jumlah tanggungan keluarga petani memiliki keeratan hubungan yang sangat lemah dengan persepsi petani terhadap penerimaan Program Perlindungan Lahan Pertanian Pangan Berkelanjutan dengan koefisien korelasi sebesar -0,157. Hubungan sangat lemah ini menunjukkan bahwa petani dengan jumlah tanggungan yang sedikit, sedang dan banyak mempunyai buka sebagai faktor persepsi petani untuk memberikan penilaian dari 
setiap atribut Program Perlindungan Lahan Pertanian Pangan Berkelanjutan.

Pada lampiran 3 menunjukkan bahwa jumlah tanggungan keluarga berpengaruh tidak nyata persepsi tingkat kepentingan petani terhadap atributProgram Perlindungan Lahan Pertanian Pangan Berkelanjutan menunjukkan bahwa jumlah tanggungan tidak menentukan persepsi yang diberikan oleh petani dikarenakan petani yang memiliki jumlah tanggungan keluarga sedikit, sedang dan banyak mempunyai kepentingan yang sama dalam menjaga lahan petaniannya sebagai modal utama dalam menjalankan usahatani yang menjadi mata pencaharian utama untuk memenuhi kebutuhan keluarga.

Hubungan koralasi luas lahan dengan persepsi tingkat kepentingan petani terhadap atribut Program Perlindungan Lahan Pertanian Pangan Berkelanjutan memiliki korelasi yang sangat lemah sebesar 0,107. Hubungan yang sangat lemah ini menunjukkan bahwa petani yang memilik luas lahan yang sedikit, sedang, dan luas mempunyai persepsi yang sama terhadap atribut Program Perlindungan Lahan Pertanian Pangan Berkelanjutan.

Hasil uji Rank Spearman menunjukkan bahwa hubungan luas lahan tidak berpangaruh nyata dengan persepsi tingkat kepentingan petani terhadap atribut Program Perlindungan Lahan Pertanian Pangan Berkelanjutan. Hal ini dikarenakan petani yang memiliki luas lahan yang sedikit, sedang dan luas memiliki kepentingan yang sama sehingga luas lahan yang dimiliki petani tidak berpengaruh dalam memberikan penilaian dari setiap atribut Program Perlindungan Lahan Pertanian Berkelanjutan.

Berdasakan Lampiran 3 di atas dapat diketahui bahwa nilai koefisiensi korelasi antara pendidikan dengan persepsi tingkat petani terhadap atribut Progam Perlindungan Lahan Pertanian Pangan Berkelanjutan di Kabupaten Garut memiliki korelasi yang lemah dengan nilai -0,328. Hasil uji Rank Spreaman menunjukan bahwa pendidikan formal berpengaruh nyata terhadap persepsi petani namun berhubungan negatif, artinya semakin tinggi tingkat pendidikan petani maka petani beranggapan tingkat kepentingan atribut program dinilai rendah.

Hubungan negatif tersebut dikarenakan petani dalam penelitian ini adalah petani yang rata-rata tingkat pendidikannya pada kategori dasar, dimana petani yang pada tingkat pendidikanya ada pada kategori dasar beranggapan sangat penting melindungi lahan pertanian kerena menjadi petani adalah profesi yang dipilih dan lahan menjadi faktor yang penting dalam menjalankan kegiatan usahatani sedangkan petani yang memiliki pendidikan lebih tinggi lebih percaya diri untuk mendapat pekerjaan yang lain jika lahan pertanian dialih fungsikan.

Hasil uji rank spreaman pada Lampiran 3 menunjukan hubungan pendapatan dan persepsi tingkat kepentingan petani terhadap atribut Program Perlindungan Lahan Pertanian Pangan Berkelanjutan di Kabupaten Garut sangat lemah dengan nilai koefisien korelasinya sebesar -0,055. Hubungan yang sangat lemah ini menunjukkan bahwa petani dengan pendapatan yang rendah, sedang dan tinggi bukan menjadi faktor bagi petani dalam menilai atribut Program Perlindungan Lahan Pertanian Pangan.

Pendapatan dengan persepsi tingkat kepentingan petani terhadap atribut Program Perlindungan Lahan Pertanian Pangan Berkelanjutan berpengaruh tidak nyata, artinya perbedaan pendapatan petani tidak mempengaruhi petani dalam memberikan persepsi, petani yang memiliki pendapatan yang rendah atau pun tinggi sama-sama memberikan persepsi relatif homogan dikarenakan petani memiliki kepentingan yang sama terhadap atribut dari setiap Program Perlindungan Lahan Pertanian Berkelanjutan. Hubungan negatif pada hasil uji Rank Spreaman dikarenakan jumlah petani yang 
berpenghasilan rendah lebih banyak dari padapetani yang berpenghasilan sedang dan tinggi.

\section{KESIMPULAN DAN IMPLIKASI KEBIJAKAN}

\section{Kesimpulan}

Kesimpulan penelitian yang telagh dilakukan dapat disimpulkan beberapa hal sabagai berikut :

Implemantasi Program Perlindungan Lahan Pertanian Pangan berkelanjutan berada tahap pendataan by name by addres 442 desa di Kabupaten Garut, sedangkan desa yang sudah dilakukan pendataan sebanyak 208 desa. Pemerintah Kabupaten Garut khusus Dinas Tanaman Pangan dan Hortikultura menargetkan diakhir tahun 2015 pendataan by name by addres sudah selesai dan membuat rancangan peraturan daerah tentang perlindungan lahan pertanian pangan berkelanjutan yang akan diajukan untuk dijadikan PERDA Kabupaten Garut. Luas lahan yang akan diusulkan nantinya akan sesuaikan dengan kebutuhan PERDA RTRW Kabupaten Garut, hal ini untuk menjaga kestabilan pertumbuhan perekonomian dan perkembangan perkotaan di Kabupaten Garut.

Persepsi tingkat kepentingan petani terhadap atribut Program Perlindungan Lahan Pertanian Pangan Berkelanjutan di Kabupaten Garut menunjukkan bahwa penerimaan petani terhadap program berada pada kategori penting dengan total rataan skor 3,09. Ini menunjukan bahwa petani memberikan persepsi tingkat kepentingan terhadap atribut Program Perlindungan Lahan Pertanian Pangan Berkelanjutan baik.

Hubungan antara persepsi petani dan karatkteristik jumlah tanggungan, luas lahan, dan pendapatan tidak berpengaruh nyata terhadap persepsi petani sedangkan umur,pengalaman usahatani dan pendapatan berpengaruh nyata $(\mathrm{p}<0,05)$ terhadap persepsi petani. Korelasi hubungan umur, pengalaman usahatani, jumlah tanggungan ,luas lahan pendidikan formal dan pendapatanberkolerasi lemah sehingga persepsi yang diberikan seragam.

\section{Implikasi Kebijakan}

Implikasi kebijakan yang dapat dilakukan yaitu pemerintah Kabupaten Garut harus mempercepat pendataan agar rancangan peraturan dearah tentang perlindungan lahan pertanian pangan berkelanjutan dapat segera diajukan, sehingga dalam pelaksanaannya ada payung hukum yang jelas untuk mencegah alih fungsi lahan pertanian sawah yang produktif ke non pertanian.

\section{DAFTAR PUSTAKA}

Badan Pusat Statistika. 2015. Produksi Padi Tahun 2014 (Angka Sementara). www.bps.go.id [ 20 juni 2015].

Rakhmat J. 2004. Psikologi Komunikasi. Edisi revisi. Remaja Rosakarya. Bandung

Riant ND. 2003. Kebijakan Publik : Formulasi, Implementasi, dan Evaluasi. PT Elex Media Komputindo Kelompok Gramedia. Jakarta.

Nazir M. 2005. Metode Penelitian. Ghalia Indonesia, Jakarta.

Sabiham S. 2008. Manajemen Sumberdaya Lahan dan Usaha Pertanian Berkelanjutan, dalam Arsyad, S dan E. Rustiandi (Ed), Penyelamatan tanah, Air, dan Lingkungan. Crestpent Press dan Yayasan Obor Indonesia.

UU No 41 Tahun 2009 tentang Perlindungan Lahan Pertanian Pangan Berkelanjutan

Wahab. S.A. 2008. Analisis kebijaksanaan : Dari Formulasi ke Implementasi Kebijakasanaan Negara. Bumi Aksara. Jakarta. 


\section{Lampiran 1}

Tabel Atribut Program berdasarkan tingkat kepentingan.

\begin{tabular}{|c|c|c|}
\hline No & Atribut & Prioritas \\
\hline 1 & Ganti rugi akibat gagal panen. & 1,5 \\
\hline 2 & Memperoleh sarana produksi dan prasarana pertanian. & 1,5 \\
\hline 3 & $\begin{array}{l}\text { Jaminan penerbitan sertifikat bidang tanah pertanian pangan } \\
\text { melalui pendaftaran tanah secara sporadik dan sistematik. }\end{array}$ & 3,5 \\
\hline 4 & Penghargaan bagi petani berprestasi tinggi. & 3,5 \\
\hline 5 & Pemberian bantuan kredit kepemilikan lahan pertanian. & 5 \\
\hline 6 & Pengembangan infrastruktur pertanian. & 8 \\
\hline 7 & Penyediaan sarana dan prasarana produksi pertanian. & 8 \\
\hline 8 & Sosialisasi peraturan perundang-undangan. & 8 \\
\hline 9 & $\begin{array}{l}\text { Penyuluhan dan pelatihan untuk peningkatan kualitas } \\
\text { sumberdaya manusia. }\end{array}$ & 8 \\
\hline 10 & Pembentukan bank bagi petani. & 8 \\
\hline 11 & $\begin{array}{l}\text { Pemberian fasilitas pendidikan dan kesehatan rumah tangga } \\
\text { petani. }\end{array}$ & 11 \\
\hline 12 & Peningkatan kesadaran dan tanggungjawab masyarakat. & 13,5 \\
\hline 13 & Keringanan pajak bumi dan bangunan. & 13,5 \\
\hline 14 & $\begin{array}{l}\text { Pengutamakan hasil pertanian pangan dalam negeri untuk } \\
\text { memenuhi kebutuhan pangan nasional. }\end{array}$ & 13,5 \\
\hline 15 & Penguatan kelembagaan petani. & 13,5 \\
\hline 16 & Pemberian bimbingan, supervisi, dan konsultasi. & 17,5 \\
\hline 17 & $\begin{array}{l}\text { Pendidikan, pelatihan, dan penyuluhan pada } \\
\text { masyarakat. }\end{array}$ & 17,5 \\
\hline 18 & Kemudahan dalam mengakses informasi dan teknologi. & 17,5 \\
\hline 19 & Harga komoditas pangan pokok yang menguntungkan. & 17,5 \\
\hline 20 & $\begin{array}{l}\text { Penyebar luasan informasi kawasan pertanian pangan } \\
\text { berkelanjutan dan lahan pertanian pangan berkelanjutan. }\end{array}$ & 20,5 \\
\hline 21 & $\begin{array}{l}\text { Pemberian fasilitas untuk mengakses ilmu pengetahuan } \\
\text { teknologi,dan infromasi. }\end{array}$ & 20,5 \\
\hline 22 & Pemasaran hasil pertanian pangan pokok. & 22 \\
\hline 23 & Pemberian fasilitas sumber pembiayaan / permodalan. & 23 \\
\hline 24 & Pencabutan insentif. & 24 \\
\hline 25 & Denda paling banyak Rp 1.000.000.000,00 (satu miliar rupiah). & 25 \\
\hline 26 & Pidana penjara paling lama 5 (lima) tahun. & 26 \\
\hline
\end{tabular}

Sumber : Data Primer yang diolah, 2015. 
Lampiran 2

Tabel Persepsi Tingkat Kepentingan Petani terhadap Program Perlindungan Lahan Pertanian Pangan Berkelanjutan di Kabupaten Garut.

\begin{tabular}{lc}
\hline Persepsi Petani & Rataan Skor \\
\hline Pembinaan & 3,4 \\
Pemberian Insentif & 3,5 \\
Perlindungan & 3,5 \\
Pemberdayaan Petani & 3,43 \\
Sanksi & 1,7 \\
\hline Total Rataan Skor & 3,09 \\
\hline
\end{tabular}

Sumber : Data Primer yang diolah, 2015. 


\section{Lampiran 3}

Tabel Koefisien korelasi karakteristik petani dengan persepsi tingkat kepentingan petani terhadap atribut Program Perlindungan Lahan Pertanian Pangan Berkelanjutan di Kabupaten Garut.

\begin{tabular}{lrc}
\hline \multicolumn{1}{c}{ Karakteristik } & \multicolumn{2}{c}{ Persepsi Petani } \\
\cline { 2 - 3 } & Koefisien Korelasi & Signifikansi \\
\hline Umur & $0,315^{*}$ & 0,168 \\
Pengalaman Usahatani & $0,389^{*}$ & 0.013 \\
Jumlah Tanggungan & $-0,157$ & 0,335 \\
Luas Lahan & 0,107 & 0,512 \\
Pendidikan Formal & $-0,328^{*}$ & 0,039 \\
Pendapatan & $-0,055$ & 0,736 \\
\hline
\end{tabular}

Sumber : Data Primer yang diolah, 2015. 